\title{
The informationization teaching ability research of higher vocational teachers under "Internet + education" background
}

\author{
Fen wei \\ Wuhan City Polytechnic, Wuhan, Hubei Province, China
}

Keywords: "Internet + education", Higher vocational teachers, Informatization, Informationization teaching.

\begin{abstract}
Informationization is the trends of world development; the informationization level has become the measure of a national modernization level and the important indicator of overall national strength. Vocational education informatization is the basis of the modernization of vocational education, teacher education informatization is an important part of vocational education informatization, is the main force of promoting vocational education informationization. Therefore, cultivate and improve school teachers' information literacy are imperative.
\end{abstract}

\section{Introduction}

China in 2020 would like to build the world level modern education system with Chinese characteristics. Construction of a high level of education system needs to have qualified teachers, teacher's responsibilities after the Internet platform; significant changes have taken place in work content. With changing in the form of the Internet, and the traditional industry fusion more and more close, the concept of "Internet +" appear, is the need of economic and social development of the new forms, is the need of the development of knowledge type society. "Internet +" combined with the traditional industry, brings new opportunities and challenges to the traditional industries, the use of information communication technology and the Internet platform, create a new generation model. Education as an important force in economic development is bound to effectively combine with the Internet [1]. The Internet with the combination of education as early as in the "Internet + " fusion, had put forward the network teaching, remote education and so on all is the use of network a convenient approach for the transmission of knowledge. The "Internet + " with the traditional industry combined with the combination of different forms, is not a simple their teaching video on the Internet, but the change of traditional teaching model, using the Internet to change teaching class model. "Internet +" era, the advent of the era of big data, education, earth-shaking changes in teaching methods for teachers' teaching requirements change, the role of the teacher there.

\section{Teachers' information technology teaching ability is the requirement of The Times}

With the steady progress of China's education information construction, information technology has become an important way to cultivate application-oriented high quality, high skills. Face the challenges of the wave of informatization, the ministry of education established to promote the modernization of education development strategy; this requires teachers to have strong ability of information technology teaching, to information technology, network resources, such as combined with teaching, form information into an important characteristic of modern classroom teaching mode [1]. In the higher vocational English teaching in information technology has become an inevitable trend. Make full use of modern information technology to deepen the reform of the higher vocational English teaching, strengthen the modern information technology and the depth of the higher vocational English teaching concept, promote higher vocational English teaching resources 
informationization construction has become an important task of the current higher vocational English teaching reform.

In the information age, information technology is every citizen must master a survival skills, higher vocational English teachers is to cultivate the high quality, high skills applied talents education workers, should have higher information literacy and information technology teaching ability [2]. The informationization teaching ability is a teacher according to the developing demand of social information environment and information technology tools to retrieve information resources, using information acquisition, processing, in order to solve the problem of practical teaching ability, in other words, is the teacher combines the modern multimedia information technology and teaching, improve teaching quality.

First, to strengthen the teaching of higher vocational English teachers' information ability training is the inevitable requirement of education informatization [2]. Education informationization is to improve the teaching quality, the important way to push forward the reform of education, is also the important guarantee of modernization of education. The education reform and development planning outline clearly put forward that information technology has a revolutionary influence on education development, should actively promote the education informatization, improve the level of education informatization;The ministry of education put forward the project of round "officer officer tong" established the becoming an information based society impetus to the development of education modernization strategy. [2], the higher vocational English teachers must strengthen information technology learning, mastering information technology teaching means actively carry out information technology teaching. At the same time, along with the development of information technology and the arrival of knowledge economy, the teachers master the information technology, the difficulty of the selection of teaching resources continue to increase, which brings many challenges to higher vocational English teachers, therefore, to deal with higher vocational English teachers' information technology training, improve teachers' information literacy.

Second, to strengthen the teaching of higher vocational English teachers' information ability training is the inevitable choice of the teaching reform. Based on technical talent training goal in higher vocational colleges are based on use for degrees, practical as the guiding ideology, in order to improve the students' vocational skills, operation ability, practical ability, expression ability and so on as the basic content of education mode [3]. Therefore, higher vocational English education should take the student as the center, to cultivate students' autonomous learning ability, language practice ability in the prominent position. Will be incorporated in the higher vocational English teaching, information technology contributes to innovative teaching methods, integrate the teaching resources, promote the interaction between teachers and students, and enhance the quality of teaching.

Third, to strengthen the teaching of higher vocational English teachers' information ability training is the need of teachers' self-development. In the higher vocational education under the environment of informatization, the informatization degree is not only a measure of informatization degree, English teachers in English teaching development level of important standard, is also an important part of its competitiveness and ability to survive [3]. Therefore, higher vocational English teachers should possess advanced informatization education thoughts and teaching ideas, information sensitivity and education have a certain foresight, renewal education idea, improve teaching methods, master information skills and techniques, is good at application information means to collect, organize and use of information resources, solve the problem of the education teaching. If the higher vocational English teachers of information technology system difficult to master, not keen ability to obtain and make use of information, will not be able to timely and effective use of education information, more can't meet the needs of the information technology teaching and scientific research.

\section{"Internet" under the background of higher vocational teachers' information technology teaching ability}

Information retrieval and information processing capacity. In the face of the complicated network resource information, if not taking the time to meet Jane, we will be a hindrance. When we mastered the retrieval method of convenient properly, choose the correct retrieval tools, access to 
information resources will be handy [4]. In addition, sometimes cannot directly use the retrieved information resources, these must be processed, the processing and integration, to become a really useful information. So, university teachers should also have the ability of information processing and integration. For example, if you want to deal with image information, usually can use, such as Photoshop software MATLAB to carry out; If to deal with the movie information, usually 3 on3dmax, Flash and other software available for, and so on. Therefore, college teachers should also master the information processing and application software operation skills.

Online learning ability. The birth of the Internet (Internet) for our production, work and study and so on all is of epoch-making significance, the Internet is like a boundless sea of knowledge, here has inexhaustible, inexhaustible knowledge information, as long as you want, you can find on the Internet, it may be said "the gang" [4].

In today's network information era of information explosion, if just by reading books to gain knowledge, then, we obtain knowledge is limited, and this way is not efficient and inefficient. As college teachers, should master the basic computer information processing technology and network technology; make full use of network resources to strengthen learning, to raise their business level and ability [4]. Network platform and the way to learn a lot, for example, many colleges and universities campus websites now, and the provincial education department and the ministry of education and other relevant institution is equipped with different types of high-quality goods curriculum website display platform, through this platform, teachers can learn how people are for curriculum construction, curriculum design and organization of course teaching, the cultivation and promotion of our college teachers teaching ability has a lot of help.

Network communication cooperation ability. With the continuous development of modern network information technology, exchange and communication between people is becoming more and more easy, more and more frequent. In virtual network environment, how to carry on the good communication with people is a new topic of new era under the new environment [5]. As college teachers, from two aspects to improve the network communication and cooperation ability: on the one hand, considering from the perspective of teaching, teachers should learn to use the multimedia technology, streaming media technology, simulation technology and virtual reality technology and so on many kinds of modern education technology, make full use of effective network information resources, based on the available network teaching platform in classroom teaching and extracurricular answer questions such as, multiple levels and student exchanges and communication between peers, realize "and so" between teachers and students; Think in terms of harmonious relationship between teachers and students on the other hand, the harmonious relationship between teachers and students is to carry out network teaching emotional foundation, therefore, college teachers and students can try to adopt new modern way of communication and exchange, to make up for the lack of communication between teachers and students in colleges and universities are widespread and the lack of emotional communication [5]. As college teachers, should learn to use and the use of E - mail (E-mail), BBS (bulletin board), FTP (file transfer system), QQ, campus BBS and other modern information transmission technology, sincerely with the students in learning, living, employment and people skills to many aspects, such as friendship-type dialogue and exchanges.

Network curriculum design capabilities. Cannot leave the network curriculum teaching, network teaching design is the key to the design of network course. College teachers to successfully on the network teaching, should be fully grasp the teaching contents, teaching objectives, teaching tasks, on the basis of careful analysis course learners (students) the knowledge and skills training demand, optimize the integration of curriculum resources, using different curriculum design software, ultimately successful design complete online course (or network courseware) [6]. Of course, network curriculum design is complicated system engineering, including many links), to invest a lot of time and energy, strengthen the team cooperation, is responsible for the design of the teachers should liaising with other relevant personnel to complete the job.

College teachers in the network course design, to realize the network course design is not simply presents the network curriculum content, and to learning activities as the main form for curriculum design, to education with vivid learning practice [6]. In the network curriculum design major should 
grasp the following four principles: first, the principle of interaction. That should have good interactivity, teachers deal with students' learning activities make corresponding evaluation, and evaluation opinion timely feedback to students. Second, the principle of intuitive interface is friendly. Interface to beautiful, conforms to the student's visual psychology, operation simple, prompt information to detailed, accurate and appropriate.

The third is individuation principle, In the curriculum design should pay attention to the cultivation of student's individualized learning and autonomous learning ability, can let the students into full play and to design show individual character and characteristic of space.

The fourth is the principle of innovation ability training. To fully reflect the cognitive subject role of students, make the student positive thinking in the process of learning, to cultivate students' innovation ability.

Ability to organize and implement the network teaching. Teaching refers to the process of teachers' teaching practice predefined. To organize the implementation of network teaching ability includes not only the teacher and the ability to answer questions using the Internet, at the same time pay more attention to the teacher to student's ability to the guidance of problem-based learning and collaborative learning [5]. Because the network teaching of teaching does not have the traditional classroom teaching in the process of organizing the implementation of site operation controllability and variability, therefore, teachers must be carefully planned well in advance the whole process of teaching, to fully consider the each link in the process of teaching, such as collaborative activities of Settings, etc.), to ensure that the entire network teaching smoothly and efficiently. Success to organize the implementation of network teaching, in addition to the requirements of college teachers teaching content itself also requires teachers to the operation of the network teaching process and the relevant instructional software, operation skills is very clear [7]. Therefore, implementation of network teaching in college teachers handle the teaching ability put forward higher requirements.

University teachers' information technology teaching ability to improve teaching efficiency and promote the development of teaching reform is of great significance, this is the majority of teachers and researchers agree. However, because of its affected by many factors, not necessarily an overnight process. Perfect system is an important step in the development process, more stable and lasting development also depends on a set of complete strategy system.

\section{Stable and effective training system}

Build system of information technology teaching ability training hard. School teachers' information technology teaching ability training should be to establish a stable system, such as each new teacher must be through the informationization teaching ability training; Every teacher must hold after the inspection certificate issued by the; Every year summer vacation time is teacher training or other fixed time; A few times a year to invite foreign teachets informationization teaching experts to lecture frontier theory school informationization teaching practice and so on, specific implementation content can be formulated by the various universities according to their own situation. Content must be relatively stable, but the premise is system execute strictly.

To determine the reasonable and frequently updated revision of the training content. Survey found that teachers have participated in various forms of computer training, after training feel harvest is very big, can be applied in the teaching practice, but feel difficult, sometimes even what to do. Investigate its reason, it is not hard to find these training mainly focus on computer technology itself, think as long as teachers master the computer technology, can be natural to use in language teaching [7].

Therefore, when determining the informationization teaching ability training content must be according to the information technology teaching ability elements of a system of integrated information technology training [7]. At the same time, because of the informationization teaching is a developing field updates fast, both theoretical knowledge and practical experience are not fixed. So for school-based training arrangement of teaching content should be in according to the forefront of the informationization teaching theory is updated frequently, avoid using a few years a set of content remains the same. 
According to the difference on the teachers' ability training by stage. Before the training should be for the current school teachers' information ability education technology evaluation and analysis of the actual situation of the investigation on the basis of this, the objective of training and training content design, formulate corresponding classification training plan [7].

For those informationization teaching knowledge is weak, the information technology ability is low beginner teachers may have a class, aims to improve their perceptual knowledge in the teaching of the informatization, help them master the application of information technology to the teaching of basic skills.

For those who had received a certain computer education, has a certain technical foundation of teachers can be through the intermediate class of developmental training, aims to further improve their design of multimedia courseware and the ability of the network courseware, as well as through the network teaching platform organize various kinds of teaching activities and the ability to achieve good teaching effect.

To have an intermediate level and can well realize information technology and curriculum integration of teachers, should establish advanced workshop, with the related research and development ability, training teachers to enable them to continuously develop more scientific, more perfect the application of information technology in the teaching of new products.

\section{Summary}

To sum up, cultivate and improve secondary vocational teachers' information literacy is a key to the modernization of vocational education. In today's degree of informatization and informatization level is so broad, based on the information technology in higher vocational English teaching reform is imperative, make full use of modern information technology to deepen the reform of the higher vocational English teaching, strengthen the modern information technology and the concept of higher vocational English teaching depth fusion, to promote higher vocational teaching informationization has become an important task of current higher vocational teaching reform.

\section{References}

[1] X. M. Zhou, The teacher role transformation theory of network teaching environment, China's science and education innovation Tribune, 2010, vol. 13, pp. 139-141.

[2] Y. B. Lin, Introduction to the composition of university teachers' teaching ability and its cultivation, Education and occupation, 2008, vol. 9, pp. 121-124.

[3] Y. F. Xie, Teachers under the network environment adaptability analysis, Journal of Yuncheng university, 2006, vol. 8, pp. 97-99.

[4] X. Q. Gu and Zh. T. Zhu, Teacher professional development mode, China audio-visual education, 2005, vol. 3, pp. 21-25.

[5] S. T. Sun, Rational research of higher vocational curriculum reform of teachers' role conversion, Tonghua normal university journal, 2015, vol. 5, ,pp. 43-46. .

[6] L. Sh. Yu, The "star" to "guide" : The transformation of the teachers' role in the information age and location, Higher education research (Chengdu), 2007, vol. 4, pp. 5-9. .

[7] B. W. Cai, Driven by project discussion teaching reform research, Journal of Jiangxi university of science and technology, 2015, vol. 4, pp. 11-14. 